\title{
SATISFACTION OF PREGNANT WOMEN WHEN CHECKING TEETH AT THE PUBLIC HEALTH CENTER
}

\author{
Ika Kusuma Wardani*1, Andi Istiqomah ${ }^{2}$, Rindang Fitriana Ulfa ${ }^{3}$, Ambika Kurnia Mustikawati ${ }^{4}$ \\ ${ }^{1,2}$ Universitas Lambung Mangkurat Banjarmasin \\ e-mail: *11ika.wardani@ulm.ac.id \\ ${ }^{34}$ Akademi Kebidanan Harapan Mulya, Ponorogo
}

\begin{abstract}
Based on a preliminary study in the Tana Lili Public Health Center area, it was found that 11 pregnant (32.2\%) had never had their teeth checked at the health center during pregnancy. Pregnant women do dental examinations at the health center or dentist if there are get toothache, cavities, bleeding gums, and others The aims of this study was to find out the description of pregnant satisfaction during dental check-ups at the health center towards the marketing mix. This research is a descriptive study with cross-sectional design. The sampling technique used purposive sampling by inclusion and exclusion criteria. The inclusion criteria in this study were pregnant women in the Tana Lili Public Health Center area who were willing to participate in this study. Exclusion criteria in this study were pregnant women who did not fill out the questionnaire completely. The number of samples in this study was 34 pregnant women.

Most of the pregnant women as many as 25 people (73.6\%) were pregnant women who had a child. Most of the pregnant women were 17 people (50\%) with high school education and the most occupations were housewives as many as 18 people (52.9\%). Most pregnant women's husbands are self-employed as many as 15 people (44.1\%). The highest family income is in the very high category, which is 13 people (38.2\%). Pregnant women are satisfied with service products are 18 people (52.94\%), price 23 people (67.65\%), promotion 24 people (70.58\%), people $22(64.7 \%)$, process 23 people (67.65\%), physical evidence 18 people (52.94\%) and very satisfied with the place are 22 people (64.7\%). Most pregnant women are satisfied with the product, price, promotion, people, process, physical evidence and are very satisfied with the places of the Tana Lili Public Health Center. Further research is needed with qualitative research to explore the reasons for pregnant women who are partially dissatisfied with promotion, people, and physical evidence so that public health center can improve their services.
\end{abstract}

Keywords: marketing mix, pregnant, satisfaction

\section{INTRODUCTION}

Based on the RISKESDAS (2013), DMF-T index in women was higher (5.0) than men (4.1). While based on the RISKESDAS (2018) the proportion of dental and oral health problems in Indonesian society is $57.6 \%$. Dental and oral health problems that received treatment by medical personnel were $10.2 \%$. Dental and oral health problems in South Sulawesi Province are in the first highest rank in Indonesia, amount $68.9 \%$. South Sulawesi data noted that North Luwu Regency was in the 5th highest rank with $73.41 \%$. Based on the data, it was found that pregnant women have a greater proportion of dental and oral health problems (Kemenkes RI, 2018). Based on a preliminary study, visits to the dentist at the public health center during pregnancy showed that $32.2 \%$ of pregnant women never checked at the public health center. Pregnant women check with the dentist because something wrong with their tooth such as toothache, cavities, bleeding gums, and others. The level of oral hygiene of pregnant women was mostly in the bad OHIS category, as much as $53.3 \%$. The results of the study using the DMF-T index showed the highest index, namely the decay index with a percentage $(72.9 \%)$. The high decay or dental caries is caused by the lack of behavior of pregnant women towards dental and oral health during pregnancy, such as brushing teeth only once a day, consuming less food containing vitamins $\mathrm{A}$ and $\mathrm{C}$, not consuming fruits between meals and not having health checks teeth and mouth during pregnancy, so that during pregnancy dental caries in pregnant women is included in 
the high DMF-T category according to WHO (Munadirah, 2017).

Pregnancy is a unique period in a woman's life due to various physical, hormonal, and behavioral changes. When a woman is pregnant, there is a changes in dental and oral health. Its caused by estrogen and progesterone. This is can be bad condition for the oral cavity of pregnant women during pregnancy. Problems that can be interfere with dental and oral health during pregnancy include hypersalivation (excess saliva), cavities, and gum inflammation. This situation will affect the growth and development of the fetus (Santoso B, 2017). Pregnant women who suffer from periodontal infections are at risk for giving birth to babies with low birth weight and having premature births (Gejir, 2017). Pregnant women will not check their dental and oral health to the dentist if dental and oral health problems are not disturbing (Gejir, 2017). In addition to efforts increase behavior of pregnant women checked, central public health are also required to participate and improve quality through marketing efforts.

Marketing is a social process by individuals and groups in society seek to satisfy patient with good services (Kotler, 2009). Meanwhile, another opinion regarding marketing is an effort to synergize a number of activities, service design, tariff/price, communication or promotion, and providing a place for service delivery that called marketing mix (Hartono, 2010). Marketing consists of actions that caused transfer of property rights to good services. The marketing process includes physical and non-physical aspects, which involve the movement that they are needed. A marketing mix is a mixture of marketing variables that can be used by a company to pursue the desired level in the target market (Kotler, 2000). Marketing mix strategy is considered as one of the core concepts of marketing theory. The marketing mix concept consists of 7Ps, namely product, price, place, promotion, people, physical evidence, and process. Each of the seven elements of the marketing mix is interrelated and dependent on each other and has an optimal mix according to the characteristics of the segment (Zeithaml, 2000).

Economic theory assumed that everyone who will consume a service product has sufficient knowledge or information about the service product. People will be considered with a product/service value by themselves if the product/service has benefit for them. In this situation, the consumer is considered to have full sovereignty. Public health center marketing efforts will make patients have more knowledge or information about services. So if marketing efforts can be implemented properly, the relationship between service providers and patients will be good (Hartono, 2010). The marketing mix is one of the marketing strategies to convey information widely, introduce a product of good services, stimulate consumers, and create personal preferences for the image of a service product. Efforts to make consumer satisfy are carried out by every company, including public health center with various strategies and methods for patients are satisfied, so they will be repeat purchases. If a patient has turned into a loyal customer because his satisfaction is fulfilled, the patient will not switch to other similar services (Selang, 2013). To give patient expectations, management must be able to explore and provide or realize in the form of services that can be felt directly or indirectly.

Based on the problem, it is important to conduct research on the views of pregnant women to visit the public health center to have their teeth checked. In addition, given that dental and oral health problems in North Luwu Regency are quite high, which is ranked 5th out of 24 regencies in South Sulawesi, the researchers are interested study with the title is satisfaction of pregnant women during dental check-up at the public health center against marketing mix.

\section{METHODS}

This research was a descriptive study with a cross-sectional approach. The data have been taken by questionnaire in the same time. The data were taken in the area of the Tana Lili Public Health Center, a sub-district in North Luwu Regency, South Sulawesi. The population in this study were pregnant women who were in the Tana Lili area from December to May 2021. Sampling in this study carried out using a purposive sampling technique. Sampling was carried out with a specific purpose by inclusion and exclusion criteria. The inclusion criteria were pregnant women who cooperative, willing to be respondents, 
physically and mentally healthy. The number of samples in this study were 34 pregnant women. Pregnant women who met the inclusion and exclusion criteria were given a questionnaire that had been tested for validity and reliability before. After obtaining the results of the questionnaire, the data were processed and analyzed by descriptive.

\section{RESULT}

The study was conducted on pregnant women in the area of the Tana Lili Public Health Center with the following characteristics:

Table 1. Tabel Frequency Distribution Number of Children Pregnant Women

\begin{tabular}{lll}
\hline $\begin{array}{l}\text { Number } \\
\text { children }\end{array}$ & Frequency & $\begin{array}{l}\text { Percentage } \\
(\%)\end{array}$ \\
\hline 1 child & 25 & 73,6 \\
2 child & 9 & 26.4 \\
\hline Total & 34 & 100
\end{tabular}

Most of the pregnant women, 25 people $(73,6 \%)$ were pregnant women who had one child.

Table 2. Table Education Frequency Distribution of Pregnant Women

\begin{tabular}{lll}
\hline Education & Frequency & $\begin{array}{l}\text { Percentage } \\
(\%)\end{array}$ \\
\hline SMP & 2 & 5.9 \\
SMA/SMK/MA & 17 & 50 \\
D2 & 1 & 2.9 \\
D3 & 2 & 5.9 \\
S1 & 9 & 26.4 \\
S2 & 3 & 8.9 \\
\hline Total & 34 & 100 \\
\hline
\end{tabular}

Most of the pregnant women 17 people $(50 \%)$ were pregnant women with high school education.

Table 3. Tabel Occupation Distribution Frequency of Pregnant Women

\begin{tabular}{lll}
\hline $\begin{array}{l}\text { Occupation } \\
\text { pregnant }\end{array}$ & Frequency & $\begin{array}{l}\text { Percentage } \\
(\%)\end{array}$ \\
\hline House wife & 18 & 52.9 \\
Honor & 1 & 2.9 \\
Entrepreneur & 13 & 38,3 \\
Civil servant & 2 & 5.9 \\
\hline Total & 34 & 100 \\
\hline
\end{tabular}

Most of the pregnant women 18 people $(52,9 \%)$ were pregnant women with housewife jobs.

Table 4. Tabel Husband Occupation Distribution Frequency of Pregnant Women.

\begin{tabular}{lll}
\hline $\begin{array}{l}\text { Husband } \\
\text { Occupation }\end{array}$ & Frequency & $\begin{array}{l}\text { Percentage } \\
(\%)\end{array}$ \\
\hline Civil servant & 5 & 14,7 \\
Honorer & 2 & 5.9 \\
Farmer & 8 & 23.5 \\
Fisherman & 4 & 11,8 \\
Enterpreneur & 15 & 44.1 \\
\hline Total & 34 & 100 \\
\hline
\end{tabular}

Most of the husbands of pregnant women as many as 15 people $(44,1 \%)$ work as entrepreneur.

Table 5. Tabel Income Frequency Distribution of Pregnant Women

\begin{tabular}{lll}
\hline Income & Frequency & $\begin{array}{l}\text { Percentage } \\
(\%)\end{array}$ \\
\hline$>3.500 .000$ & 13 & 38.2 \\
$2.500 .000-$ & 2 & 5.9 \\
3.500 .000 & & \\
$1.500 .000-$ & 7 & 20.6 \\
2.500 .000 & & 35,3 \\
$<1.500 .000$ & 12 & 100 \\
\hline Total & 34 & \\
\hline & Most of the family income of pregnant \\
women is in the high category, 13 people \\
(38.2\%) with income $>3,500,000$.
\end{tabular}

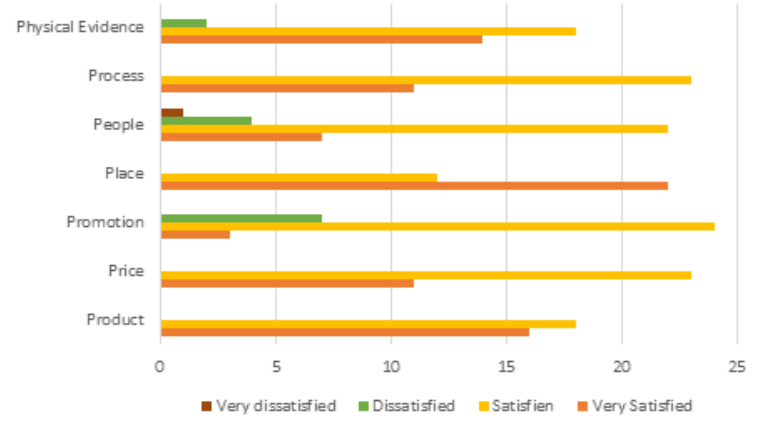

Figure 1. Graph Frequency Distribution of Pregnant Women's Satisfaction with Marketing Mix (Product, Price, Promotion, Place, People, Process, Physical Evidence)

Most pregnant women satisfied with the dental services at public health central facilities during their pregnant. Although some parts were dissatisfied with promotion, people, and physical evidence.

\section{DISCUSSION \\ Satisfaction Pregnant Women with the Product during Dental Check-Up at the Public Health Center}

Based on the results of the study, most of the respondents 18 pregnant $(52.9 \%)$ rated the product as satisfied and 16 people $(47.1 \%)$ rated very satisfied. Satisfaction with the product judged by the usefulness of the product for pregnant women, well-known 
public health center services, the equipment used, there is always a dentist who checks, the complete service, medicines and pregnant women feel that the services provided by public health services were high quality.

Products can't be ignored because the product is an important element in a marketing program. Product strategy can influence other marketing strategies. According to Lupiyoadi (2009), the product shows an opportunity to added value for patients who in this case are pregnant women. Purchasing a health service product is not just to try the product, but also to meet the needs and desires of patients (Kotler, 2009).

Lestari (2018) stated that in the era of globalization, the improvement quality of health care products/services should be greater. Therefore, health service expected to prepare itself to develop the organization, especially the resources and systems from the arrival of similar industry competitors. Health services were the one of the services that required to be able to win the competition. For this reason, health services must be able to provide quality health services for patients. Quality health services are product advantages to win the competition. The results of this study are in line with research by Nurhalimmah (2008) which stated that good quality service products have a significant relationship with patient repeat visits.

\section{Satisfaction Pregnant Women with the Price during Dental Check-Up at the Public Health Center}

Based on the results of the study 23 people $(67.65 \%)$ pregnant women considered satisfied with the price. While 11 people $(32.35 \%)$ rated very satisfied. The assessment was satisfied by pregnant women because pregnant women feel that the existing tariff with the quality of service, affordable rates according to the patient's ability, easy payment methods, and could be using health insurance.

Price is the amount of money that charged for a product or service. Price is the value given to patients who in this case are pregnant women for the benefits of a product or service. Based on the results of the study, it can be seen that most of the family income of pregnant women was included in the very high category. So pregnant women who come for a check-up will not have a problem with the price given. According to Lestari (2018), price is not a problem if it is give more benefit with the services.

In economics, the price, value, and utility were interrelated concepts. It is meant by the utility was an attribute attached to an item/service, which allowed the product/service to fulfill needs, wants, and satisfy consumers. Value was the value of a product in exchange for other products. Value could be seen in a barter situation, but already uses money as a measure called price. So, the price was the value of an item/service expressed in money (Buchari, 2008). Therefore, it is expected that health services should be oriented to service quality to be able to compete. If the price was accordance with the quality of service, the patient will choose the same services and it can reach high level of visits (Lestari, 2018).

Satisfaction Pregnant Women with the Promotion during Dental Check-Up at the Public Health Center

Based on the results of the study, most of the 24 people (70.59\%) were satisfied, 3 people $(8.82 \%)$ rated very satisfied while the 7 people $(20.58 \%)$ rated dissatisfied. The assessment of satisfaction with the promotion was assessed from the promotions carried out by the pubic health center through banners, radio or social media so that pregnant women easily find out about the public health center program about dental and oral health services, easily find out information from friends and easily find out the types of services available at the public health center.

Promotion is a process of communicating marketing mix variables that was very important to be implemented by companies in marketing products. The essence of promotion activities was a form of marketing communication activity that seeks to disseminate information, influence, remind the target market to be willing accept, buy, and be loyal to the products offered by a service. One way that a health service can do to attract patients' interest with products was to carry out promotional activities (Lestari, 2018).

The results of this study were in line with research conducted by Wijayanti (2015) which concluded that a well-executed promotion will have an impact on increasing the number of patient visits. This research also in line with Purnamasari's research (2011) which showed there was a relationship 
between promotion and patient visits in the outpatient unit of the Mother and Child Hospital of Makassar.

Satisfaction Pregnant Women with the Places during Dental Check-Up at the Public Health Center

Based on the results of the study 22 people $(64.71 \%)$ rated the place as very satisfied, 12 people (35.29\%) were very satisfied. Satisfaction was obtained when pregnant women feel that the public health center was easy to reach by public transportation, strategic, has a large parking area, near home, and does not take a long time to get to the services.

The choice of location in a business was the main thing to consider. Strategic location was the one of important factors and greatly determines the success of a business. Business location is related to transportation efficiency issues, and ease reaches by consumers, in this case pregnant women. The location also affects patient comfort (Lestari, 2018).

The results of this study were in line with the results of Maratush's (2015) research which stated that place had an effect on the interest in repeat visits of JKN patients. The results of this study were also not different from the research by Pondaag (2015) which stated the factors that influence implementation of marketing mix is place.

Satisfaction Pregnant Women with the People during Dental Check-Up at the Public Health Center

Based on the results of the study, it was found that 22 people $(64.7 \%)$ rated satisfied, 7 people $(20.59 \%)$ rated very satisfied, 4 people $(5.89 \%)$ were dissatisfied and only 1 person rated very dissatisfied. The level of satisfaction for people assessed based on the friendliness of the officers, explanations of medical personnel, response to complaints, and the skills of the officers.

The results of this study were in line with Lestari's research which stated that a good human resource factor will make the patient comfortable so that it has an impact on the patient's loyalty to always visit if there were illness. The results of this study were also in line with research by Wijayanti (2015) which concluded that people had an impact on increasing the number of patient visits. The results of this study were also the same as the results of Maratush's research (2015) which stated that people affect the interest in patient repeat visits.

Satisfaction Pregnant Women with the Process during Dental Check-Up at the Public Health Center

Based on the results of the study obtained 23 people $(67.65 \%)$ were satisfied and 11 people $(32.35 \%)$ very satisfied. The assessment on the process was obtained from indicators of dentists who responsive in providing services, do not require long times, easy and fast registration, doctors who serve had many skill, on time, and had good services for complaints.

The results of this study were in line with Lestari (2018) which stated that the process was important and needs to be considered for a health service. The process could be affect in patient loyalty because it related to the service was provided to patients. The process includes service procedures. The speed and accuracy of the process can be used as a tool to stimulate consumer interest, such as fast and precise patient admission procedures, fast and precise examination, care services, nurses/doctors perform service schedules correctly, officers perform services without convoluted.

Satisfaction Pregnant Women with the Physical Evidence during Dental Check-Up at the Public Health Center

Based on the results of the study 18 people $(52.94 \%)$ satisfied with the physical evidence, 14 people $(41.17 \%)$ rated very satisfied, and 2 people $(5.88 \%)$ rated dissatisfied. The assessment was based on the criteria for a comfortable, clean, and tidy waiting room and the good appearance of the officers.

The results of this study were in line with research conducted by Wijayanti which concluded that physical evidence had an impact on increasing the number of patient visits. This study was also in line with Lestari's research (2018) which stated that physical evidence was related to the level of patient visits at the Sahid Sahirman Hospital.

Physical evidence was something that significantly influences consumer decisions to buy and use the products and services offered. This elements included in physical facilities, 
physical environment (physical buildings), equipment, logo, colors, and other items. A patient can immediately conclude a health facility good by first sees the physical facilities in the health facility (Lestari, 2018).

\section{CONCLUSION}

Most pregnant women satisfied with marketing mix of the Tana Lili Public Health Center. Further research will be needed for qualitative research to explore the reasons pregnant women that dissatisfied with promotion, people, and physical evidence to improve the public health center services.

\section{REFERENCE}

Buchari Alma dan Ratih Hurriyati, Manajemen Corporate Strategi Pemasaran Jasa Pendidikan. Bandung : Alfabeta. 2008. Hlm 306

Firdaus M. Manajemen Agribisnis. Jakarta: PT Bumi Aksara; 2010.

Gejir IN, Sukartini NK. Hubungan Kebersihan Gigi dan Mulut dengan Trimester Kehamilan pada Ibu Hamil yang Berkunjung ke Puskesmas Klungkung I Kabupaten Klungkung tahun 2016. Jurnal Kesehatan Gigi. 2017;5(1) :1-2

Hartono B. Manajemen Pemasaran untuk Rumah Sakit. Jakarta: Rineka Cipta; 2010.

Kementerian Kesehatan RI. Riset Kesehatan Dasar RISKESDAS 2013. Indonesia : Kementerian Kesehatan RI 2013

Kementerian Kesehatan RI. Riset Kesehatan Dasar RISKESDAS 2018. Indonesia : Kementerian Kesehatan RI 2018

Kotler P dan Keller. Manajemen Pemasaran. Jilid 1. Edisi ke 13. Jakarta: Erlangga; 2009.

Kotler P. Manajemen Pemasaran. Edisi Milenium. Jakarta: PT Indeks Kelompok Gramedia. 2000

Lestari, Puji Rindu. Hubungan Pemasaran Rumah Sakit (Marketing Mix) 7P terhadap Tingkat Kunjungan Pasien. Jurnal Ilmu Kesehatan Masyarakat; 2018

Lupiyoadi Rambatdan A Hamdani, Manajemen Pemasaran Jasa (Jakarta : Salemba Empat, 2009) hlm. 86 - 91

Mar'atush SA dan Susanto. Pengaruh Bauran Pemasaran (Marketing Mix) Terhadap Minat Kunjungan Ulang Pasien Jaminan
Kesehatan Nasional (JKN) Di Unit Rawat Jalan Rsud Panembahan Senopati Bantul. Jurnal Online; 2015

Munadirah, Gambaran Perilaku Ibu Hamil terhadap Kesehatan Gigi dan Mulut di Kelurahan Sapaya Kecamatan Bungaya Kabupaten Gowa. Media Kesehatan Gigi.2017; 16 (1): 15 - 17

Nurhalimmah F dan Sugiarsi S. Gambaran tingkat kepuasan Pasien Rawat Jalan Kunjungan Ulang di Rumah Sakit PKU Muhammadiyah Karanganyar. Jurnal Kesehatan; 2008

Pondaag C dan Massie K. Pelaksanaan Bauran Pemasaran Dalam Upaya Peningkatan Jumlah Kunjungan Pasien Di RSUD Amurang. Jurnal Online; 2015

Purnamasari AH. Nurhayani, Asiah $\mathrm{H}$ dan Yusran A. Hubungan Bauran Pemasaran (Marketing Mix) Dengan Kunjungan Pasien Di Unit Rawat Jalan RSIA Pertiwi Makassar ; 2011.

Santoso B, Sutomo B. Pengaruh umur kehamilan, tingkat pengetahuan tentang menyikat gigi terhadap Derajat Kebersihan Gigi dan Mulut pada Ibu Hamil di Kelurahan Bintaro Kabupaten Demak. Jurnal Kebidanan. 2017; 6 (13); 65

Selang. Bauran Pemasaran (Marketing Mix) Pengaruhnya Terhadap Loyalitas Konsumen Fres Mart Bahu Mall Manado. Jurnal EMBA. Manado: Universitas Sam Ratulangi; 2013.

Wijayanti SD, Amir MY dan Indar. Hubungan Bauran Pemasaran Dengan Loyalitas Pasien Di Unit Rawat Jalan RSUD Kota Makassar. Jurnal Online; 2015

Zeithaml VA dan Bitner MJ. Service Marketing integrating Cutomer Focus Across The Firm. Second Edition Hill. New York: McGraw; 2000. 